\title{
Paideusis
}

\section{Multiculturalism in Canadian Society: A Re-evaluation}

\section{Romulo F. Magsino}

Volume 12, Number 1, 1998

URI: https://id.erudit.org/iderudit/1073093ar

DOI: https://doi.org/10.7202/1073093ar

See table of contents

Publisher(s)

Canadian Philosophy of Education Society

ISSN

0838-4517 (print)

1916-0348 (digital)

Explore this journal

Cite this article

Magsino, R. (1998). Multiculturalism in Canadian Society: A Re-evaluation.

Paideusis, 12(1), 7-21. https://doi.org/10.7202/1073093ar

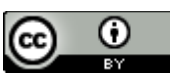

This document is protected by copyright law. Use of the services of Erudit (including reproduction) is subject to its terms and conditions, which can be viewed online.

https://apropos.erudit.org/en/users/policy-on-use/
This article is disseminated and preserved by Érudit.

Érudit is a non-profit inter-university consortium of the Université de Montréal, Université Laval, and the Université du Québec à Montréal. Its mission is to promote and disseminate research.

https://www.erudit.org/en/ 


\title{
Multiculturalism in Canadian Society: A Re-evaluation
}

\author{
Romulo F. Magsino, The University of Manitoba
}

\section{Introduction: Multiculturalism under Siege}

The Canadian policy of multiculturalism within a bilingual framework, once viewed here and abroad as a bold experiment in managing cultural diversity and as Canada's "outstanding contribution to the field of race and ethnic relations" (Fleras and Elliott, 1992, p. 2) may not last long or energetically enough to fulfil its promise. It was originally conceived in 1971 as an instrument of national unity within a pluralistic society and was favourably received by the Canadian public. At the moment, the policy appears hopelessly ill-fated. Intended officially to embed and strengthen multiculturalism in law and policy, the federal Multiculturalism Act (Canada, 1988) and provincial pieces of legislation adopting multiculturalism are subject to changing political and economic tides. Though the Canadian Charter of Rights and Freedoms (Canada, 1982) requires the interpretation of its provisions in ways that conform to the multicultural heritage of Canadians, its governmental and legal implementation is uneven and its ramifications remain uncertain. Certainly in the last ten years or so, the espousal of multiculturalism has been silenced by an undeserved, uninformed backlash.

In this paper, I revisit the justification for the Canadian policy of multiculturalism in the light of negative, high-profile works of such writers as J.L Granatstein (1998), William Gairdner (1990), Reginald Bibby (1990), and Neil Bissoondath (1993, 1994). In an earlier paper (Magsino, 1989), I argued that the policy is justifiable insofar as it publicly commits government to the principles of unity, equality, and freedom of cultural retention for multicultural groups. Here $I$ focus on the question of cultural retention in relation to the notion of national unity and set aside the issue of equality. I take it that, in our democratic society, the case for equality of opportunity and participation in various spheres of Canadian life for minority group members is a compelling one.

\section{The Popular Critique of Multiculturalism: National Unity and the Case for Traditional Core}

Ironically, the multicultural policy that is to unite Canadians is, for Granatstein, one which promotes not only separatism but also "the idea among immigrants ... that Canada and, in particular, English-speaking Canada has no culture and no nationality of its own" (Granatstein, 1998, pp. 86-87). Equating 'nationality' with 'national identity,' he recognizes that, in important ways, Canada has not been a melting pot like the United States with its unifying nationalist myths and assimilationist ethos. Yet, against the federal government's desire to foster Canadian identity based on justice, peace, and compassionate solidarity, he insists on Canadian identity based on the "history and the heritage that Canadians share" (pp. 92-93). In one breath, he attempts to put forward the arguable view that Canada has one history to teach with the problematic claim that it has one cultural heritage-the predominantly English- 
speaking one-to inculcate in everyone. While it may be true that Canada has one history that continues to be documented, and setting aside the view that it is subject to varied interpretations, Canadian history has been shared with the Aboriginals, the French, and a host of later immigrants. The reason that it is an English-speaking history and heritage is that, through use of force, the English were successful in imposing their will on the others. Granatstein is to be commended for not wanting "children to be taught an airbrushed history of Canada with all the warts removed" (p. 103). Nonetheless, he is too quick in claiming that, "because immigrants have come to a formed society, they must accept its ways and adapt to its norms," and that, "while they may keep as much of their native culture as they wish, they must pay the costs involved" (pp. 84-85). Presumably, this mean spiritedness to the immigrants' backgrounds is for the sake of the newcomers themselves. The government, Granatstein insists, should turn immigrants "into Canadian citizens as quickly as possible by giving them the cultural knowledge they need to understand and to thrive in our society" (p. 85).

Granatstein's denial of cultural retention in the name of assimilating immigrants to promote their economic well-being in a new land sounds noble when compared to Gairdner's single-minded eurocentrism. For Gairdner (1990), multiculturalism needs to be scrapped because it works toward the silent destruction of English Canada by undermining the country's core values and way of life which undergird the nation's stability and unity. The foundation of national unity and stability, he asserts, is natural similarity or homogeneity. Against this, multiculturalism emphasizes equal acceptance of natural differences and, imposed by government on the majority, breeds fear and hostility (Gairdner, pp. 392-393). His solution to the consequent fractiousness is predictable:

The only successful way to end such fractiousness is first to find a natural cultural system that works; then to enoourage everyone to assimilate to it, thus gradually losing their prior differences. The English culture and system of government have been just such a solution, as Canada's peaceful development until very recently attests. For it was only assimilation to the high moral standards of freedom and responsibility under our English governing institutions that had any hope of dissolving these fractious and bloody differences. (p. 395. Author's underlining)

Gairdner's conception of unity is quite blunt and disturbing. It is not co-operation and harmony among equally respectful and appreciative cultural groups; it is, rather, through the predominant sway of the traditional way of life and values-English, for Gairdner-which has been imposed on all minority ethnic groups such that peace and harmony have been achieved in this country. Indeed, Gairdner (1990, p. 393) casts an envious glance not only at the Japanese who view their homogeneity as essential to their political stability and economic success, but also at many Asiatics who apparently believe that society is strongest when its members all come from the same race or ethnic group. Unfortunately, Gairdner appears to inhabit a world apart from the real one in which we live. Unable to increase its population due to a low birth-rate; in need of more people, more technical skills, and more human power for economic development; and unable to entice its traditional immigration sources, Canada has had to rely on other sources for its purposes. And, with its immigration points system, it has attracted from Asia, Africa, Latin America, and other 
places, many of their best, who have made tremendous contribution to Canada's economic development. Now that one-third of Canadians do not have exclusive British or French origin, Gairdner's longing for homogeneity is in vain. The drive for assimilation and homogeneity, whether paternalistic (Granatstein) or imperialistic (Gairdner), is bound to fail. Not only does it go counter to experiences in many places, including the United States, where the melting-pot strategy has not been much of a success in eliminating, or extinguishing, the desire for recovering at least certain aspects of the minorities' ethnic identities. If anything is true, it is that the present drive for equality by ethnic groups has engendered a politics of recognition that cannot be ignored or underestimated (Taylor, 1992b). Where peoples profess their differences, yet demand equal opportunities and participation in society, the imperial imposition of cultural and political hegemony by one particular group-even the predominant majority-is clearly not the way to attain unity. It is sad that multiculturalism critics like Gairdner and Granatstein remain myopic to the lessons of past and present societies where atrocities and warfare are waged due to the powerful group's imperialistic policies over the others. As Gurr has recently pointed out on the basis of research on politically active ethnic and communal groups, "grievances about differential treatment and the sense of group cultural identity provide the essential bases for mobilization ..." (Gurr, 1990, p. 124). If the debacles of the Meech Lake and Charlottetown accords demonstrate anything, it is that minorities-at least in Canada-can muster enough support to frustrate governmental processes or objectives which are perceived to compromise their dual aspirations toward equality and identity. Indeed, as Cairns (1995) observes with apprehension, the politics of minoritarianism, stimulated by the Charter of Rights and Freedoms and other contemporary developments, is now a reality in Canada. Clearly, an inflexible policy of assimilation, argued passionately by Gairdner and Granatstein, is likely to generate discord, if not strife, rather than the harmony they hope for.

\section{The Fear of 'Mosaic Madness' and Relativistic Pluralism}

Reginald Bibby sees in the policy of multiculturalism the seeds of disunity because it produces 'individual mosaic fragments.' Straying from the discipline required of sociologists, he seems to accept the view that "greater preoccupation with one's own group makes one more distant from and antipathetic to others" (Bibby, 1990, pp. 10-11), although he admits that evaluation research on the impact of multiculturalism on tolerance and respect for one another is barely started. Naively, he assumes, as many do, that relativism provides the philosophical underpinning for the modern phenomenon of pluralism (pp. 9-10), and finds multiculturalism worrisome insofar as it enshrines the latter. In his words (pp. 103-104):

When a country like Canada enshrines pluralism through policies such as multiculturalism and bilingualism and the guaranteeing of individual rights, the outcome is coexistence-no more, no less. It's a good statt in building a society out of diverse peoples. But there's a danger. If there is no subsequent vision, no national goals, no explicit sense of coexistence for some purpose, pluralism becomes an uninspiring end in itself. Rather than coexistence being the foundation that enables a diverse nation to collectively pursue the best kind of existence possible, coexistence generates into a 
national preoccupation. Pluralism ceases to have a cause. The result: mosaic madness.

Reflectively or not, some multiculturalists themselves often compromise the policy by adopting cultural relativism. The assumption is readily made that it is impossible to make value judgements on different ways of life because different societies have varying circumstances-geographic, demographic, economic, socio-political, and the like. Now, we may grant that lots of incommensurability of values, beliefs, attitudes, and behaviour among different cultural groups may be expected. Further, insofar as our ways of perceiving, conceiving, and forming our world views are coloured and shaped by the limited lenses provided by our respective cultures, we will need to be cautious in judging the ways and values practiced in other cultures. Thus, different cultures may have to be understood and appreciated, to a large degree, on their own terms.

However, although cultural differences need to be treated with initial respect, a thorough-going cultural relativism will prove disastrous to the policy of cultural retention for minority ethnic communities. As Granatstein puts it, the Canadian culture or civilization is Western, and "there is no reason we should be ashamed of it or not wish to teach our students about it." Inheritors of the Greek and Roman traditions, and the British and French experience, "the West is the dominant civilization in the world today in part because its values have been tested and found true." Accordingly, "that immigrants, who have come here because they want to buy into our civilization and value system, should be told to retain their culture, is wrong-headed in the extreme"' (Granatstein, 1998, p. 101-102). If cultural relativism holds true, how is one objectively to take issue with a supercilious assimilationist bent on imposing cultural domination against ethnocultural groups? Why may not a dominant group enforce its iron will on every minority community-after all, it can, on the basis of its own value system, pre-emptively pursue its goal of protecting and preserving its own culture? Where relativism prevails, where every group is right and no group is wrong, the rule of the dominant, powerful group is the absolute rule. Change comes only by way of power struggle or revolution. But not only is this unrealistic for ethnic groups in a country like Canada; it is also a prescription for either chaos or resignation.

Relativism, whether individual or cultural, is a hindrance to a policy aimed at uniting peoples. Except where self-serving convenience is furthered, it provides no morally compelling basis for accommodation and pursuit of common goals. It destroys our faith that we live in a common world and share a common humanity. Thus, pursuit of pluralism based on relativism is frightening indeed and ought to be resisted. But this is a pseudo-problem seized by the enemies of multiculturalism for their assimilationist purposes. Bibby and other critics who misperceive that the policy is grounded on relativistic pluralism need not worry. Multiculturalism is rooted on solid grounds.

\section{Undermining Unity Through Divided Loyalties and Marginalization}

Neil Bissoondath $(1993,1994)$ finds it disturbing that some Canadians are doggedly monarchists, others are pro-American, and still others are francophone. Worse, "To such fracturing must now be added a host of new divisions actively encouraged by our multiculturalism policy ... "' (1993, p. 375). 
Multiculturalism, "in encouraging the wholesale retention of the past," not only makes it impossible for immigrants to develop wholehearted commitment to the new land and its ideals and visions but also encourages them to import with them ethnic, religious, and political hatreds from their countries of origin. The consequence is that, failing to see the enemy of the past as a fellow Canadian, the immigrant lives with "suspicion, estrangement, vandalism, physical attack, and death threats; it is yet another aspect of the multicultural heritage that we seek to preserve, promote, and share" (pp. 376-377).

Moreover, as Bissoondath sees it, multiculturalism assumes "that people, coming here from elsewhere, wish to remain what they have been; that personalities and ways of doing things, ways of looking at the world, can be frozen in time. ... It treats newcomers as exotics and pretends that this is both proper and sufficient" (1993, p. 372; also quoted in Bissoondath, 1994, p. 43). One deleterious consequence is that mainstream Canadians find it easy to dissociate from new Canadians because "differences, so close to the surface are seized upon [and] are turned into objects of ridicule and resentment" (p. 379).

Bissoondath's Selling Illusions: The Cult of Multiculturalism in Canada (1994) is perhaps the most sustained popular attack against the country's multiculturalism policy. A sampling of his criticisms will reveal the fuller thrust of his comments above.

Depending on stereotype, ensuring that ethnic groups will preserve their distinctiveness in a gentle and insidious form of cultural apartheid, multiculturalism has done little more than lead an already divided country down the path to further social divisiveness. (p. 90)

It is desperately sad, when after many years they see Canada as only that (i.e., a job); and it is even sadder when their children continue to see Canada with the eyes of foreigners. Multiculturalism . . . serves to encourage such attitudes. (p. 133)

But multiculturalism ends where our notions of human rights and dignity begin ... . The Multiculturalism Act suggests no limits to the accommodation offered to different cultural practices . . . . Can Canada accommodate citizens whose loyalties do not ompass its long-established legal system? (pp. 138-139)

Multiculturalism .... has heightened our differences rather than diminished them; it has preached our differences rather than encouraging acceptance; and it is leading us into a divisiveness so entrenched that we face a future of multiple solitudes with no central notion to bind us. (p. 192)

\section{Bissoondath's Problems: Response And Critique}

Bissoondath has attracted much attention, and there is no doubt that his popular book and television appearances have lent a persuasive voice questioning the Canadian multiculturalism policy. He is not only an accomplished writer but also a coloured native from Trinidad and is, therefore, seen as a credible spokesperson on multiculturalism. Nonetheless, his case against the policy is far from successful. His apparent lack of familiarity with the policy, his lack of conceptual or logical sophistication, and his lack of understandings drawn from sociological and ideological, rather than literary, insights all contribute to his passionate but definitely misguided position. 


\section{Lack of Familiarity with the Policy}

Because Bissoondath unhesitatingly criticizes the Canadian policy of multiculturalism not only for compromising national unity but also marginalizing, and impeding equality for, minority groups, it is important to revisit the notion of Canadian multiculturalism and the principles it espouses.

Burnet (1983) has pointed out that the term 'multiculturalism' arose in the 1960s in Canada to focus on a new reality in contrast to its officially-accepted policy of biculturalism. This claim is buttressed by the fact that this term is nowhere to be found in social science encyclopaedias published until late in the 1960 s or even in recently published dictionaries. Instead, as the 1984 edition of the International Encyclopedia of Sociology states, the noted economist J.S. Furnival introduced in 1948 the culturally-oriented concept of a plural society by referring to a society with a variety of peoples who differ physically, linguistically, and religiously, and who occupy different positions in the division of labour (Magsino, 1989). Indeed, 'cultural pluralism' has been the standard expression until the more recent political and sociological volumes, and 'multiethnic education' has been the favoured term particularly in the American context.

Though some observers claim that 'multiculturalism' means what its writer wants it to mean, clearly this is not the case if we are talking about Canadian multiculturalism. At least the official statements on this policy focus on a number of principles which provide the essential signification for this term. In the statement delivered by former Prime Minister Pierre Trudeau in the House of Commons on October 8,1971, the principles of national unity, freedom of cultural retention, equality, and mutual respect and appreciation are clear in certain passages concerning the policy's general intent:

Such a policy (of multiculturalism within a bilingual framework) should help to break down discriminatory attitudes and cultural jealousies. National unity, if it is to mean anything in the deeply personal sense, must be founded on confidence in one's own individual identity; out of this can grow respect for that of others and a willingness to share ideas, attitudes, and assumptions. It can form the base of a society which is based on fair play for all (Trudeau, in Mallea \& Young, 1984, p. 519).

Short as the official statement is, its references to "overcoming cultural barriers to full participation in Canadian society," to promoting "creative encounters and interchange among all Canadian groups in the interest of national unity," and encouraging groups' contribution to "regional and national ways of life in ways that derive from their heritages" unmistakably reflect the principles.

Within twenty or so years, some provincial governments and the federal government have passed policies and/or pieces of legislation confirming the principles first enunciated in Trudeau's proclamation. Thus, the federal Multiculturalism Act (Canada, 1988) states, among others, as follows:

3(1) It is hereby declared to be the policy of the Government of Canada to

(c) promote the full and equitable participation of individuals and communities of all origins in the continuing evolution and shaping of all aspects of Canadian society and assist them in the elimination of any barrier to such participation... 
(e) ensure that all individuals receive equal treatment and equal protection under the law, while respecting and valuing their diversity;

(g) promote the understanding and creativity that arise from the interaction between individuals and communities of different origins.

The Manitoba Multiculturalism Act (Manitoba, 1992) is no less explicit:

It is hereby declared to be the policy of the Government of Manitoba to

(b) recognize and promote the rights of all Manitobans, regardless of culture, religion, or racial background to

(i) equal access to opportunities

(ii)participate in all aspects of society, and

(c) enhance the opportunities of Manitoba's multicultural society by acting in partnership with all cultural communities and by encouraging co-operation and partnerships between cultural communities.

Earlier pieces of legislation or statements of policy in other provinces reiterate these principles (see Magsino and Singh, 1986). In light of these documents, anyone who sympathizes with the policy may justifiably experience puzzlement, if not outright consternation, in Bissoondath's misguided and ignorant jousting against the intent of the policy.

The ignorance is made even more glaring because Bissoondath's comments reveal absolute lack of knowledge about multicultural education which multiculturalists have spearheaded and which became embedded in the curriculum and practices in many school systems in just about every province in the country. When he observes that multiculturalism fails to develop in students "a sense of identity, critical consciousness, and belonging"' (1994, p. 141), or when he comments as if schools are not mindful of a particular goal of multicultural education-namely, to "foster tolerance of the varying backgrounds and beliefs of others sharing this planet" (p. 185)-one must see the truth in the commonplace that little learning is a dangerous thing.

\section{The Need for Conceptual and Logical Rigour}

Bissoondath's sustained allegation that the policy fosters disunity and compromises minorities, notwithstanding its explicit goals, is perhaps not entirely inexplicable. His stance may be due to his failure to distinguish between two aspects of the policy. One aspect pertains to its nature and intent. As a statement of governmental commitment, it embeds principles which, apparently, Bissoondath himself advocates. But an aspect of the policy involves its implementation, and this is what Bissoondath might predominantly have in mind in his uncompromising critique. There is a world of difference between the principles which a policy is intended to pursue and their implementation. Conceivably, real shortcomings have hobbled the latter, not the least of which is the absence of co-ordinated focus. The policy initially centred on cultural retention, particularly in the form of symbolic ethnicity, to the neglect of the other principles. Promotion of cultural symbols to enhance a sense of identity on the part of ethnic groups and the encouragement of cultural sharing of these symbols to promote mutual appreciation and respect occupied the attention of the multicultural community and the government. This explains the common criticism that multiculturalism dealt with the exotic and the symbolic, which presumably did not do much to promote the well-being of minority groups. Arguably, the value 
of symbolic ethnicity cannot be underestimated and, thus, it should not readily be set aside. Nonetheless, the narrowness of this focus was recognized and emphasis shifted to anti-racism and anti-racist education. Still lacking in coordinated multi-pronged thrust, the policy implementation moved in another direction with the passage of the Multiculturalism Act. As Fleras and Elliott (1992, p. 78) put it,

It is obvious that passage of the Multiculturalism Act has altered the government's priorities for managing Canada's burgeoning diversity. This reflects a change in government policy from the folkloric focus of the 1970s to the anti-racist agenda of the early 1980s and the emphasis on justice and social equality in the late 1980 s.

Needless to say, the policy has not changed in terms of its conception and its embedded principles. The strategic implementation has shifted, however, and Bissoondath's relentless attack on the exotic and the symbolic reflects his failure to know or understand what is going on.

It is unfortunate that Bissoondath, in his eagerness to bury multiculturalism, fails to distinguish between the policy and certain ideological positions which he and other overly enthusiastic multiculturalism critics associate with it. Without our prejudging Bissoondath's case against his adversaries in Chapter 8 , "Diversity and Creativity" in Selling Illusions, it is clear that his attacks are really against views or ideologies outside the intent of the policy. Thus, while he might have an arguable case against those that may appropriately be categorized as involved in the "politically correct" (P.C.), he is clearly out of bounds when he assumes that their acts of commission or omission are undertaken in the name of multiculturalism. Indeed, in this chapter and in many other parts of Selling Illusions, Bissoondath heavily engages in numerous non sequitors. All interesting literary stuff, but what have they got to do with multiculturalism? Surely multiculturalism is not intended to curtail freedoms (as P.C. critics assume multiculturalism is), to advocate reverse discrimination, or to encourage wholesale importation of ways and beliefs repugnant to Canadians as human beings. The policy is intended to achieve unity as the body politic balances the aspirations of ethnocultural groups for respect for their cultural identity and for full participation in a free society. The balancing is not easy, and no policy can provide in advance what Bissoondath wants-an extensive, hard and fast set of guidelines or rules governing the workings of the policy. Democracy involves some experimentation and ambiguity in living with one another. In any culturally diverse society composed as it is of peoples with different beliefs and values, the road to unity is paved not by unbending resistance to others or by intransigent criticism of one another but by inculcating mutual understanding and appreciation and by accommodating one another. This is precisely what the multiculturalism policy has explicitly advocated. If there remains ethnocentricity among ethnocultural members (as Bibby maintains), or if they remain blindly committed to their original values, beliefs, and ways such that they carry on with their reprehensible hatreds and conflicts originating from their homelands (as Bissoondath claims), or if fanatics go beyond the spirit of multiculturalism, then it certainly is not a failure of the principles embedded in the policy. In fact, the policy is intended to combat individual or group discord arising from ethnocentricity and to promote accom- 
modation of one another. It may be that policy implementers have designed implementation plans that do not include properly conceived strategies, effective programs, and/or adequate financial outlay; or those of us who ought to support its implementation may not be doing enough. But to charge the policy as the cause of disunity, to blame it for contributing to ethnocentricity or continued conflicts among former enemies in the new homeland, and to blame it for the excesses of irrational ideologues, certainly show an ignorant and inexplicable failure to understand what the policy is all about.

That there are certain loose ends in the policy's implementation may be conceded, however. Notwithstanding his many misdirected and misconceived criticisms, Bissoondath (1994) correctly observes that the policy may appear to encourage cultural retention and, thus, give the impression that cultural groups may import wholesale their cultural ways into the country. This is admittedly to court disaster. But the anticipated problem is more imagined than real. Clearly, individuals who decide of their own free will to immigrate to another country realize that cultural adjustment is largely to be on their part. This may well be true even in the case of refugees forced out of their own countries by circumstances beyond their control. In any case, even if we grant, as Bissoondath claims, that some ethnic groups prefer wholesale cultural importation, they are realistic enough to know that they do not have the resources for it, and that existing societal institutions will not accommodate this preposterous idea. Closer to reality, ethnic groups themselves do not expect to live in the host country in much the same way they lived in their country of origin. All they ask is that elements of their culture, which they hold dear and sacred, are preserved and perpetuated, albeit in some modified way, to fit their new circumstances.

The real difficulty is that some things which people hold dear or sacred from their original culture may be in conflict with fundamental values or principles held in the host culture. The controversy between the Sikhs on the one hand, and the Legion of Veterans on the other, involving the use of the former's headgear in the latter's halls is a reminder that passions are aroused by conflict of traditions, beliefs, or values. It is worth noting that such conflicts also arise among different groups within the mainstream society. Thus, unless we wrongheadedly insist on the unattainable dream of cultural homogeneity, we must realistically countenance the occasional occurrence of conflicts in society. In this regard, multiculturalism is to be regarded as a policy of realism rather than illusions in its attempt to foster more understanding among, and mutual appreciation of, different cultural groups. In any case, inevitable as the occurrence of such conflicts may be, our democratic system provides a means of resolution. At the first instance, the political system may offer possibilities for compromise. Failing this, the legal system is available as a final resort.

\section{The Need to Understand Realities in a Diverse Society}

The egalitarian thrust of the multiculturalism policy has been explicit from the start. By and large, this thrust is shared even by critics of multiculturalism, and for incontrovertible reason. Equality, together with freedom, has been the moral and political principle or value pursued by democratic societies everywhere. Based on human worth, and insistent that each person deserves respect and equal concern (Dworkin, 1977), equality at least in terms of having access to what one justly deserves as a human being is difficult to dispute. 
Thus, the intent of writers, such as Bissoondath (and Porter, 1965, for that matter) to promote the socio-economic and political parity for minority ethnic groups is unquestionable. What is problematic is that they automatically assume that minority groups and their members have to pay a price for this parity over and above what the privileged and advantaged groups need to pay. And the price exacted of them is high: renunciation of the cultural heritage which has given them the identity that they already have. What is expected of them is a substantial transformation such that linguistically, cognitively, and in most other ways, they are able to compete on equal terms with mainstream Canadians. Their original culture is presumably a burdensome baggage which ethnic members had better discard if they are to succeed in life.

Yet, it is not clear precisely what it is from one's original culture that the immigrant ethnic member must forsake to succeed in the new culture. Must one forsake one's religious beliefs which, in many cases, shape how one reacts and lives in the new environment? In a democratic society, this is simply too much to expect. Must one renounce stereotypically perceived predispositions, such as apparent timidity and lack of drive to compete and succeed? Contrary to this perception, it is not reasonable to assume that such predispositions are naturally part of the new immigrant's psychological constitution, given that immigrating to an unknown land is in itself an indication of adventurousness and willingness to take on new risks in life. Nowhere is there any evidence that immigrants lack the drive to succeed; contrariwise, there is plenty of evidence to show that the net effect of failures in their search for jobs, due to institutional structures, requirements, and arrangements which militate against new immigrants (Henry, et al., 1995), is what brings about resignation and despair on their part. Or, must one deliberately dissociate oneself from one's ethnic community and soak the new culture in by associating with the host people alone? But why would we deny the immigrant, already uprooted psychologically and physically from a familiar environment, the sense of security and belonging available from one's ethnic community? Besides, is there any guarantee that the host community will bend backward to support the struggling immigrant? Perhaps the immigrant must forsake his/her native language to master the new one. But, having already learned and spoken a native language, one is not likely to speak another one without an accent or some difficulty. One may learn the vocabulary of the workplace; to all intents and purposes, this is all that one needs to do a good, even outstanding, job. Unfortunately, one's accent and imperfect grammar is frequently mistaken for lack of intelligence or ability.

The renunciation of ethnicity in the name of economic mobility presumably also entails ensuring that children become enculturated in the host culture. This may not be regarded as a serious concern. Enculturation of young people in school and within their peer group is inevitable. In fact, ethnic parents' and ethnic communities' complaints center on the difficulty which they encounter in influencing the thinking and behaviour of their children (Magsino, 1982). There is substantial evidence that the socializing force of assimilation is much too strong for the comfort of parents who worry about the indiscriminate enculturation of their children against their wishes.

But Bissoondath unduly worries about the negative parental ways and perspectives which they have brought with them from their homelands. He insists on the young's adoption of western ways and abilities which he himself 
appears to have fully internalized. If he can assimilate so effortlessly, why can not the other immigrants? One answer, naturally, is that not all immigrants had the same predispositions and circumstances as Bissoondath. Repelled by things he found in his country, and fortunate enough to travel abroad and develop a westernized outlook, he could not appreciate the depth of attachment which other Trinidadians, or other immigrants to Canada, for that matter, have to their native lands, their native tongues, their religions and, indeed, those ways and beliefs that have helped to make them what they are. For Bissoondath, there is a need to override one's cultural identity in the name of unity and equal participation in the host country. Canadian society marked by unity and diversity.

Well-meaning as Bissoondath is, one is rightly repulsed by his view that we contribute to our marginalization by adhering to our cultural ways and symbolic ethnicity. This view is almost tantamount to blaming the victim: "Too bad that you are what you are; unless you change, you do not deserve respect and equal treatment in Canada!" Apparently unsympathetic to his original culture, Bissoondath may not have realized that his own western ethnocentricity rears its ugly head through his amalgamationist views. But more than this, his fortunate circumstances and personal success, and his lack of familiarity with relevant and incontrovertible literature on discrimination, have hidden from his view the reality not only of prejudice but also individual, institutional, and systemic discrimination in Canada. It is so pathetic that one could almost hear him say: "Do not worry about your physical attributes; as long as you think and speak and act like a mainstream Canadian, you'll be fine!"

\section{Appreciating Deep Diversity As Expression Of Humanity}

Anticipating the demise of multiculturalism, Bissoondath (1994, p. 224) lyricizes about his vision of Canada:

\footnotetext{
Whatever may come after multiculturalism will aim not at preserving differences but at blending them into a new vision of Canadian-ness, pursuing a Canada where inherent differences and inherent similarities meld easily and where no one is alienated with hyphenation. A nation of cultural hybrids, where every individual is unique, every individual distinct. And every individual is Canadian, undiluted and undivided.

The ultimate goal, then, is a cohesive, effective society enlivened by cultural variety: reasonable diversity within vigorous unity. We already have the first. Now we must have the second, even if that would mean-as it must-a certain diminishment of the first.
}

This vision can be very seductive, at least initially because it sounds so much like what the Canadian multiculturalism policy is advocating.

Yet, Bissoondath's quoted statement at the beginning of this section gives some hint on why his vision is antithetical to the present policy. Clearly, he does not find it problematic that, in pursuing "vigorous unity," the result will eventually be the diminishment of reasonable diversity. Lacking in appreciation of his original culture, and concerned with the attainment of commonality needed for unity, he is more than willing to give up any minority group's cultural heritage. Indeed, he would leave cultural heritage within the realm of the family and remove it from the sphere of public policy and, thus, governmental responsibility. Cultural heritage will have to sink or swim by itself. He could not care less about the fact that the net, general effect of leaving cultural 
heritage to the family or community is amalgamation and loss of diversity. Research has demonstrated again and again the power of assimilative forces in society. Without support from governmental policy and action, the family and community are bound to lose the battle for cultural retention. Bissoondath does not seem to have known about this at all and, of course, had he known, this would have been the least of his worries.

In any case, there are critical problems in Bissoondath's vision. First, he speaks of "inherent differences" and "inherent similarities" as if they were self-revealing or self-identifying. The use of the term "inherent" is puzzling because we know that culture, no matter how entrenched and stable, is a social product subject to change, albeit exceedingly gradual in some societies. The term can hardly describe a cultural practice, unless what is meant is that there are cultural ways, beliefs, and performance that belong specifically to a group because of the genetic make-up of its members. But Bissoondath will be hardpressed to show that genetically determined ways, beliefs, and performances exist, what they are, and that they are (equally) valuable and ought, therefore, to be (equally) appreciated. Second, Bissoondath is guilty of the same charge of undue open-endedness that he levels against Canadian multiculturalism. The policy, we might recall him claiming inaccurately, allows ethnocultural groups to determine what they want to retain, no matter how unacceptable they are to society. For his part, to show his accommodation of cultural retention, he speaks of "reasonable diversity." But when is this "reasonable diversity" reasonable? What standards of reasonableness are going to be employed, and who are to formulate them? Are they the standards which the mainstream community, through their spokespersons or leaders, will be authorized to determine? Is so, on what grounds may minority groups accept them?

Perhaps the most revealing problem that can be raised against Bissoondath is related to the fact that, unlike many immigrants, he has had no appreciation of his cultural heritage or any attachment to his original community. Impressed by his own personal achievement within the mainstream community; not bothered by any loyalty to his cultural community, from which he gladly escaped in the first place; and adhering to the unquestioning liberal faith that unity is dependent on the commitment of each de-contextualized, individualistic citizen, he can glibly speak of this country as a society of "undiluted and undivided" Canadians. Imagine a Canada of self-made individuals; forget about the place of communities and the role they play in personal and cultural development. Surely, people with strong communal links and appreciation of their cultural heritage will reject Bissoondath's perspective. For all his fervour, his vision of a "cohesive, effective society enlivened by cultural variety" is so vague that perhaps even he does not know what it is likely to be. Whatever it is, for certain it will be one in which cultural diversity has virtually no meaningful place.

Bissoondath's abiding faith in individualism, coupled with his denigration of one's cultural community, is disturbing. If nothing else, the recent debate between liberal and communitarian theorists reveals that liberalism, grounded as it is in the ideology of individualism which eschews the influence of community and insists of personal autonomy, seriously misperceives and underestimates the role of community in the development of the individual and in the formation of individual projects in life. Liberal theorists (e.g., Galston, 1991; Kymlicka, 1989; Macedo, 1990) bave recognized this and attempted to re-interpret 
liberalism to accommodate the role of one's cultural context or community in the development of the human being and in the definition of one's identity. Taylor (1992b, pp. 40-41) captures this point eloquently:

I can define my identity only against the background of things that matter.

But to bracket out history, nature, society, the demands of solidarity, everything but what I find in myself, would be to eliminate all candidates for what matters. Only if I exist in a world in which history, or the demands of nature, or the needs of my fellow human beings, or the duties of citizenship, or the call of God, or something else of this order matters crucially, can I define an identity for myself that is not trivial. (Underlining Taylor's.)

The individual develops and maintains identity in a certain type of culture with its own activities and ways, but these "do not come into existence spontaneously." In Taylor's words, "they are carried on in institutions and associations which require stability and continuity and frequently also support from society as a whole-almost always the moral support of being commonly recognized as important, but frequently also considerable material support" (Taylor, 1985, p. 205). In a society made up of different cultures in which individuals develop and maintain their identities, these cultures need to be recognized and supported if they are to continue their vital role. Beyond this instrumental role, Taylor suggests the presumption that "we owe equal respect to all cultures" (Taylor, 1992, p. 66) because of their intrinsic worth. This presumption claims that "all human cultures that have animated whole societies over some considerable stretch of time have something important to say to all human beings" (ibid.). Thus, cultures have both instrumental and intrinsic values; their easy dismissal as part of the drive for diminished diversity in the name of vigorous unity should, therefore, be questioned.

Beyond instrumental and intrinsic values attributable to culture, as noted by Taylor, it is arguable that respect for minority cultures can be anchored on a strong, objective moral ground. As some Canadian writers (Coombs, no date; Wright and LaBar, 1984; Magsino, 1989) have insisted before, the policy of multiculturalism can be justified in terms of the most fundamental moral principle of the dignity of, and respect for, human beings or persons (henceforth, respect for persons) from which other principles are drawn. As a fundamental principle, respect for persons arises from the ineluctable fact that human beings have certain characteristics-namely, susceptibility to suffering and frustration and the capacity to form and act on intelligent conceptions of how their lives should be lived (Dworkin, 1977; Quinton, 1973). Respect for each person demands that each being be accorded equal concern: the right to equal treatment, "that is, to the same distribution of goods or opportunities as anyone else has or is given;" and the right to treatment as an equal, that is, "the right, not to an equal distribution of some good or opportunity, but the right to equal concern and respect in the political decisions about how these goods and opportunities are to be distributed" (Dworkin, p. 273). But respect for persons also implies treating them as ends and never only as means. As a being with human potentialities and capacities, each person must be regarded as an agent capable of formulating and pursuing purposes of her own (Milne, 1986, p. 82). As an autonomous agent, she is entilled to demand freedom from interference by others in relation to her choices, being, and property (Benn, 1988, p. 108). 
Assuming that members of different ethnic communities are no less human than mainstream members of the host community and, thus, assuming that these members are entitled to respect as persons, it becomes clear that their entitlement to freedom and well-being goods is undeniable. As human beings with physical, psychological, cognitive, and other needs, they have the right to equal concern and to equal consideration of their interests. Such a right calls for the performance of the positive obligation (which is no less than what is expected by mainstream members) owed them by societal institutions charged with the responsibility for society's well-being. Moreover, as rational beings with cognitive and agency capacities of their own, ethnic members are equally to be allowed their free or autonomous choices in different spheres of life. Such autonomy or freedom must include the right to determine whether to retain, develop, or reject elements of their original cultural heritage in their new homeland. Thus, insofar as their well-being is intricately linked to their ethnic community, and insofar as they choose to retain important elements of their cultural heritage in ways that are permissible in time, governments can no longer feign economic hardship to justify their clearly inadequate multiculturalism policy implementation, multicultural educators and ethnocultural groups may legitimately expect them to demonstrate decisively their political commitment to the policy through financial allocation and systematic implementation leadership. For their part, notwithstanding the fiery backlash fuelled by lack of knowledge, unfounded fears, or resentment, multicultural educators need to pursue the policy with renewed vigour. A policy, which closely reflects respect for all individuals as human beings, should serve as an inspiring guide in the moral enterprise called education.

\section{References}

Benn, S. (1988). A theory of freedom. Cambridge: Cambridge University Press.

Bibby, R. (1990). Mosaic madness. Toronto: Stoddart Publishing.

Bissondath, N. (1993). A question of belonging: Multiculturalism and citizenship. In W. Kaplan (Ed.), Belonging: The meaning and future of Canadian citizenship. Montreal \& Kingston, ON: McGill-Queen's University Press.

Bissoondath, N. (1994). Selling illusions: The cult of multiculturalism in Canada. Toronto: Garamond Press.

Burnet, J. (1983). Multiculturalism. In J.H. Marsh (Ed.), The Canadian Encyclopedia. Edmonton: Hurtig Publications.

Cairns, A. (1995). Reconfigurations: Canadian citizenship and constitutional change. Toronto: McClelland \& Stewart.

Canada. (1982). Constitution Act. R.S.C., 1985, Appendix II, No. 44. The Canadian Charter of Rights and Freedoms

Canada. (1988). An Act for the Preservation and Enhancement of Multiculturalism in Canada (Bill C-93). House of Commons.

Coombs, J. (No date). Multicultural education and social justice. Xerox copy.

Dworkin, R. (1977). Taking rights seriously. Cambridge: Cambridge University Press. 
Fleras, A. \& Elliott, J. (1992). Multiculturalism in Canada. Scarborough, ON: Nelson Canada. backs.

Gairdner, W. (1990). The trouble with Canada. Toronto: General Papersity Press.

Galston, W. (1991). Liberal purposes. Cambridge: Cambridge Univer-

Granatstein, J.L. (1998). Who killed Canadian history? Toronto: Harper-Collins Publishers.

Gurr, T. (1993). Minorities at risk: A global view of ethnopolitical conflicts. Washington, DC: United States Institute for Peace.

Henry, F., et. al. (1995). The colour of democracy: Racism in Canadian society. Toronto: Harcourt Brace \& Company.

Kymlicka, W. (1989). Liberalism, community, and culture. Oxford: Clarendon Press.

Macedo, S. (1990). Liberal virtues. Oxford: Clarendon Press.

Magsino, R. (1982). Tropical islanders in the Atlantic: A study of Filipino experiences in Newfoundland. St. John's, NF: Memorial University Printing Services.

Magsino, R. (1985). The right to multicultural education: A descriptive and normative analysis. Multiculturalism, 9(1).

Magsino, R. (1989). Multiculturalism in schools: Is multicultural education possible and justifiable? In S. Morris (Ed.), Multicultural and intercultural education: Building bridges. Calgary: Detselig Enterprises.

Magsino, R. \& Singh, A. (1986). Toward multicultural education in Newfoundland and Labrador. St. John's, NF: Memorial University Printing Services.

Manitoba. (1992). The Manitoba Multiculturalism Act. (Bill 98). Manitoba Legislative Assembly. Winnipeg, MB.

McLaren, P. (1998). Life in schools. An introduction to critical pedagogy in the foundations of education. New York: Longman.

Peters, R.S. (1966). Ethics and education. London: Allen \& Unwin.

Porter, J. (1965). Vertical mosaic. Toronto: University of Toronto Press. Paul.

Quinton, A. (1973). The nature of things. London: Routledge \& Kegan

Taylor, C. (1985). Philosophy and the human sciences. Cambridge: Cambridge University Press.

Taylor, C. (1992a). The ethics of authenticity. Cambridge, MA: Harvard University Press.

Taylor, C. (1992b). Multiculturalism and the politics of recognition. Princeton, NJ: Princeton University Press.

Trudeau, P.E. (1984). Statement by the Prime Minister in the House of Commons, October 8, 1971. In J. Mallea \& J. Young (Eds.), Cultural diversity and Canadian education. Ottawa: Carleton University Press.

Wright, I. \& LaBar, C. (1984). Multiculturalism and morality. In S. Shapson \& V. D'Oyley (Eds.), Bilingual and multicultural education: Canadian perspectives. Clevedon, Avon, England: Multilingual Matters. 